\title{
Intestinal Expression of Human Apolipoprotein A-IV in Transgenic Mice Fails to Influence Dietary Lipid Absorption or Feeding Behavior
}

\author{
Katriina Aalto-Setälä, * Charles L. Bisgaier," Ann Ho, " Karen A. Kieft," Maret G. Traber," Herbert J. Kayden," \\ Rajasekhar Ramakrishnan, 'Annemarie Walsh, * Arnold D. Essenburg,' and Jan L. Breslow* \\ ${ }^{*}$ Laboratory of Biochemical Genetics and Metabolism, and ${ }^{\ddagger}$ Laboratory of the Biology of Addictive Diseases, The Rockefeller University, \\ New York 10021; \$ Department of Pharmacology, Parke-Davis Pharmaceutical Research, Division of Warner-Lambert Company, Ann \\ Arbor, Michigan 48105; "Department of Medicine, New York University Medical Center, New York 10016; and 'Department of \\ Medicine, College of Physicians and Surgeons, Columbia University, New York 10032
}

\begin{abstract}
Two transgenic mouse lines, expressing low or high amounts of human apo A-IV were created. In low and high expressor HuAIVTg mice on a chow diet, serum human apo A-IV levels were 6 and 25 times the normal human level and on a high fat diet, they were 12 and 77 times higher. Human apo A-IV was equally distributed between lipoprotein (mainly HDL) and lipid-free fractions. Intestinal absorption of radiolabeled cholesterol and triglycerides was unaffected in HuAIVTg mice. Vitamin A, carried exclusively in chylomicrons and their remnants, was catabolized normally. When an intragastric vitamin $\mathbf{E}$ bolus is given to the HuAIVTg mice, the initial absorption and appearance in triglyceride-rich lipoproteins was similar to that observed in normal mice. However, elevated amounts of vitamin $E$ were subsequently observed in the VLDL of the HuAIVTg mice. Furthermore, in the fed state, serum VLDL triglycerides were markedly elevated in HuAIVTg mice. This effect was greater in high expressor mice. Serum total cholesterol was not elevated, but the distribution was altered in the HuAIVTg mice; VLDL-C was increased at the expense of HDL-C. Kinetic studies suggested a delayed clearance of VLDL in HuAIVTg mice. Apo A-IV has been suggested to be a satiety factor, but no effect on feeding behavior or weight gain was observed in these HuAIVTg mice. In summary, our studies with HuAIVTg mice show that additional apo A-IV does not effect intestinal absorption of fat and fat-soluble vitamins, and at least chronic elevation of plasma apo A-IV does not effect feeding behavior in this model system. (J. Clin. Invest. 1994. 93:1776-1786.) Key words: apolipoprotein A-IV • lipoproteins - very low density lipoprotein kinetics • vitamin A • vitamin E
\end{abstract}

\section{Introduction}

Apo A-IV is a 46-kD, 376-amino acid glycoprotein found principally in HDL and the lipoprotein-free fraction of plasma (110). The apo A-IV gene is expressed mainly in the intestine with varying degrees of liver expression in different species (11-12). The apo A-IV gene is located in a complex with the

Address correspondence to Jan L. Breslow, The Laboratory of Biochemical Genetics and Metabolism, The Rockefeller University, 1230 York Avenue, Box H29, New York, NY 10021-6399.

Received for publication 8 September 1993 and in revised form 7 January 1994.

J. Clin. Invest.

(c) The American Society for Clinical Investigation, Inc.

0021-9738/94/04/1776/11 \$2.00

Volume 93, April 1994, 1776-1786 apo A-I and apo CIII genes (13-14). Apo A-I and apo A-IV genes are transcribed in the same direction, whereas the apo CIII gene located between them is transcribed in the opposite direction (1). Studies in transgenic mice have suggested that an intestinal control region for the entire gene complex resides between the apo CIII and apo A-IV genes (15).

A number of physiological functions for apo A-IV have been postulated, including a role in fat and fat-soluble vitamin absorption. Apo A-IV levels are increased in plasma after a fat-containing meal and a chronically fed high fat diet elevates plasma levels $(3,6,16-22)$. Patients receiving total parenteral nutrition without lipids have low or undetectable apo A-IV levels (20). A single patient with genetic deficiency of apo A-I, CIII, and A-IV had low plasma levels of vitamin A, vitamin E, and essential fatty acids (23), whereas patients with apo A-I and CIII, but not A-IV deficiency had normal levels (24-27). These associations plus almost exclusive intestinal expression of this protein in humans plausibly suggest that apo A-IV is involved in fat and fat-soluble vitamin absorption.

Apo A-IV has also been suggested to play an important role in feeding behavior. Fujimoto and his co-workers (28) found that apo A-IV-rich lymph or purified apo A-IV functioned as a satiety factor in rats, and that this function was not shared by apo A-I. Later, they demonstrated that this anorexic effect was mediated through the central nervous system (29).

Other functions for apo A-IV have also been postulated. Steinmetz and Utermann (30) have shown that apo A-IV can activate lecithin:cholesterol acyltransferase (LCAT) in vitro, but this function can also be carried out by other apolipoproteins. DeLamatre (31) and Bisgaier (9) have shown that in vitro incubation of plasma with apo A-IV during the lecithin:cholesterol acyltransferase reaction causes a depletion of HDL surface lipids and increased HDL-associated apo AIV. These studies suggest a structural role for apo A-IV in stabilizing HDL as the LCAT reaction proceeds. Other studies (32) have suggested apo A-IV may function in the removal of cellular cholesterol from extrahepatic tissues. Again, this is not a unique function for this apolipoprotein. However, since lipidfree apo A-IV is present in high concentrations in interstitial compartments, it is an ideal candidate to perform this function. Other studies have suggested apo A-IV functions in HDL clearance via a specific hepatic receptor (33). However, the theory of whether apo A-IV functions as a ligand for clearance of whole HDL has been challenged (34). Finally, it has also been suggested by Goldberg et al. (35) that apo A-IV modulates lipoprotein lipase activity by regulating the distribution of its activator apo C-II between HDL and lipolysis susceptible substrates such as chylomicrons. It is possible that this protein serves a variety of functions. 
To gain further insights into the role of apo A-IV in lipid metabolism, transgenic mice expressing human apo A-IV (HuAIVTg) ${ }^{1}$ were created. In the current study, we mainly focused on the role this apolipoprotein might play in intestinal lipid absorption and feeding behavior. Lipid absorption was measured using a variety of metabolic tracers, including the fat-soluble vitamins $\mathrm{A}$ and $\mathrm{E}$ and radiolabeled cholesterol and triglycerides. The intestinal absorption of these lipids was normal despite $>20$ times higher apo A-IV levels than normally found in human plasma. We also failed to detect any effect of chronically elevated plasma apo A-IV levels on appetite or weight gain. In addition, these mice displayed feeding behavior and consumed amounts of food that were indistinguishable from control mice.

\section{Methods}

Creation of HuAIVTg. A 10-kb DNA fragment containing the human apo A-IV gene was constructed from three overlapping genomic fragments extending from the PvulI site in the most $5^{\prime}$ region of the apo CIII gene to the HindIII site $\sim 1 \mathrm{~kb}$ to the $3^{\prime}$ of the apo A-IV gene (Fig. 1). Transgenic mice were created by microinjecting the $10-\mathrm{kb}$ construction into male pronuclei of fertilized mouse eggs as described by Walsh et al. (36).

Tail tip DNA from 3-wk-old mice was screened for human apo A-IV by the polymerase chain reaction (37). Primers were chosen to identify the intergenic region adjacent to the human apo CIII gene (38). No amplification could be detected in DNA obtained from nontransgenic mice.

Two transgenic mouse lines (C57Bl6xCBA) expressing human apo A-IV were created; low and high expressor lines. Nontransgenic litter mates or F1 mice were used as controls. Mice were housed in a temperature-controlled room with an alternating light ( 7 a.m.-7 p.m.) and dark period ( 7 p.m. -7 a.m.). Mice were fed either mouse chow (Purina Mills, St. Louis, MO) or high fat (Adjusted Calories Western-type Diet no. 88137, Teklab Premier Laboratory Diets, Madison, WI) diets and had access to water, ad libitum. This sodium cholate-free high fat diet contained by weight, $21 \%$ fat (polyunsaturated/saturated $=0.07$ ), $0.15 \%$ cholesterol, and $19.5 \%$ casein. Male and female mice, 3-4 mo of age weighing 20-30 g were used for experiments. Experiments were performed between 8 a.m. and 11 a.m. with ad libitum-fed mice (fed state), unless otherwise indicated. In some studies, food was removed from the cages at 9 a.m., and blood samples were collected from the mice $8 \mathrm{~h}$ later (fasted state). Mice were anesthetized with methoxyflurane before retroorbital plexus blood sampling or intragastric bolus administration of lipid. For femoral vein injections, mice were anesthetized with pentobarbital.

Human and mouse apo A-IV quantitation. Human and mouse apo A-IV was quantitated by immunoelectrophoresis (39) with antibodies raised in rabbits against human (6) and rat apo A-IV (40), respectively. The latter cross-reacts with mouse apo A-IV. The antibody to human apo A-IV did not recognize mouse apo A-IV and vice versa. Apo A-IV levels in pooled plasma from four normolipidemic human subjects was $19 \mathrm{mg} / \mathrm{dl}$. This was quantitated using purified human apo A-IV kindly provided by Dr. Marian C. Chung (Washington University, Seattle, WA) and it was set to be one arbitrary unit. The amounts found in HuAIVTg mice were expressed relative to this amount as arbitrary units. Quantitation of mouse apo A-IV in control and HuAIVTg mice was also expressed in arbitrary units relative to a standard prepared from a mouse plasma pool $(100 \mathrm{ml}$ ) obtained commercially (Pel-Freez Biologicals, Rogers, AR ). Serum samples or gel-filtration column fractions (FPLC Superose 6; Pharmacia LKB Biotechnology, Piscataway, $\mathrm{NJ}$ ) were diluted in $4 \mathrm{M}$ urea, $12 \mathrm{mM}$ Tricine, $40 \mathrm{mM}$ Tris, $0.6 \mathrm{mM}$ calcium lactate, and $0.01 \% \mathrm{NaN}_{3}, \mathrm{pH} 8.2$, and incubated for $30 \mathrm{~min}$ at

1. Abbreviations used in this paper: HuAIVTg, human apolipoprotein A-IV transgenic; LCAT, lecithin:cholesterol acyltransferase.

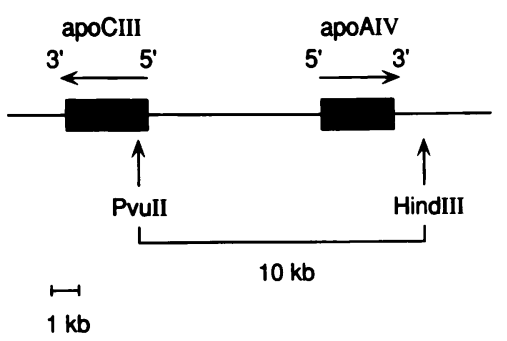

Figure 1. DNA fragment used to create HuAIVTg mice. An $\sim$ 10-kb DNA fragment from chromosome 11 containing the human apo A-IV gene was constructed from three overlapping genomic fragments extending from the PvuII site in

the most $5^{\prime}$ region of the apoCIII gene to the HindIII site $\sim 1 \mathrm{~kb}$ to the $3^{\prime}$ of the apo A-IV gene. This construct was microinjected into male pronuclei of fertilized mouse eggs to create two separate transgenic lines expressing low or high levels of human apo A-IV.

$37^{\circ} \mathrm{C}$ before immunoelectrophoresis. Appropriate dilutions of HuAIVTg and control mouse serum or column fractions were made to determine apo A-IV in the linear range of the assay. Overnight immunoelectrophoresis was carried out on GelBond film (Category no. 53748, FMC Corp. BioProducts, Rockland, ME) containing either $6 \%$ rabbit anti-human or $9 \%$ rabbit anti-rat apoA-IV serum in $1 \%$ agarose, $2 \%$ polyethylene glycol 6000 in $24 \mathrm{mM}$ Tricine, $81 \mathrm{mM}$ Tris, $1.2 \mathrm{mM}$ calcium lactate, and $0.02 \% \mathrm{NaN}_{3}, \mathrm{pH} 8.2$, at $1 \mathrm{~mA} / \mathrm{cm}$. Rocket height was determined on amido black-stained gels.

Apo A-IV mRNA analysis. Liver, small intestine, spleen, heart, kidney, stomach, adipose tissue, and muscle total RNA were extracted from control and HuAIVTg mice (41) and Northern blotted (20 $\mu \mathrm{g}$ total RNA/lane) on nylon filters. Blots were prehybridized at $65^{\circ} \mathrm{C}$ with $300 \mu \mathrm{g} / \mathrm{ml}$ salmon sperm DNA, $5 \times \operatorname{SSPE}(1 \times \mathrm{SSPE}=0.15 \mathrm{M}$ $\mathrm{NaCl}, 10 \mathrm{mM}$ EDTA, $10 \mathrm{mM}$ sodium phosphate, $\mathrm{pH} 7.4$ ), 0.5\% SDS, $0.2 \%$ Blotto, $50 \%$ formamide, and hybridized in the same solution using either human or mouse apo A-IV specific riboprobes. Filters were washed with $2 \times \mathrm{SSPE}, 0.2 \%$ SDS and $0.2 \times \mathrm{SSPE}, 0.2 \%$ SDS at $65^{\circ} \mathrm{C}$. The specific riboprobes represented basepairs $500-552$ of the mouse (42) and the corresponding area in human apo A-IV gene, which were the least homologous regions between the two species. The probe for human apo A-IV did not react with mouse apo A-IV mRNAs and vice versa.

Vitamin A-fat tolerance test. Four control and four high expressor HuAIVTg mice with serum triglyceride levels of $144 \pm 33$ and $201 \pm 92$ $\mathrm{mg} / \mathrm{dl}$, respectively, were given an intragastric bolus of retinyl palmitate $(3,000 \mathrm{U})$ in corn oil $(100 \mu \mathrm{l})$. Mice were bled $(60 \mu \mathrm{l})$ before and $\mathrm{l}$, 2,4 , and $12 \mathrm{~h}$ after the challenge. Retinyl acetate internal standard was added to serum samples before lipid extraction (43). Samples were reconstituted with toluene and analyzed by reverse-phase HPLC (Beckman Instruments, Inc., Fullerton, CA), using $2 \mathrm{ml} / \mathrm{min}$ methanol as the mobile phase (44). Peak area of retinyl palmitate was normalized to that of retinyl acetate.

Intestinal triglyceride production. To determine intestinal triglyceride production, three control and three high expressor HuAIVTg mice normally maintained on a chow diet were fasted overnight and treated with Triton WR 1339 ( $500 \mathrm{mg} / \mathrm{kg}$ i.v.) to block lipolysis (45). Mice were given an intragastric bolus of glycerol $\left[{ }^{3} \mathrm{H}\right]$ trioleate $(50 \mu \mathrm{Ci})$ in corn oil $(100 \mu \mathrm{l})$. Blood samples were drawn $30,45,60$, and $90 \mathrm{~min}$ thereafter. $\left[{ }^{14} \mathrm{C}\right]$ trioleate internal standard was added to serum sample, and lipids were extracted according to the method described by Folch et al. (46). Triglycerides were separated by thin-layer chromatography on silica gel G (Analtech Inc., Newark, DE) in hexane-diethyl etheracetic acid ( $82: 16: 1 \mathrm{vol} / \mathrm{vol} / \mathrm{vol})$, and radioactivity was determined by liquid scintillation counting.

Cholesterol absorption. Cholesterol absorption was determined in five control and five high expressor HuAIVTg mice maintained on a chow diet by the double-label technique described by Zilversmit (47). Mice received $\left[{ }^{3} \mathrm{H}\right]$ cholesterol $(5 \mu \mathrm{Ci})$ intravenously $(2.5 \%$ ethanol in $0.9 \% \mathrm{NaCl})$ and $\left[{ }^{14} \mathrm{C}\right]$ cholesterol $(5 \mu \mathrm{Ci})$ in skim milk as an intragastric bolus. The ratio of $\left[{ }^{14} \mathrm{C}\right]$ cholesterol to that of $\left[{ }^{3} \mathrm{H}\right]$ cholesterol was 
measured 43, 53, 61, and $77 \mathrm{~h}$ after radiolabeled cholesterol administration to determine the percent of cholesterol absorbed.

Vitamin E assay. Vitamin E absorption was determined in eight control and seven high expressor HuAIVTg mice maintained on a chow diet. [ $\left.3,4{ }^{14} \mathrm{C}\right]$ all-racemic- $\alpha$-tocopherol $(122 \mu \mathrm{Ci} / \mathrm{mg})$ dissolved in toluene, a gift from Dr. W. Cohn, Hoffman-La. Roche Inc. (Basel, Switzerland), was taken to dryness under nitrogen in the dark and then was resuspended in corn oil. Mice were given an intragastric bolus of $\left[{ }^{14} \mathrm{C}\right]$ vitamin $\mathrm{E}(10 \mu \mathrm{Ci})$ in corn oil $(100 \mu \mathrm{l})$. Animals were bled (30 $\mu \mathrm{l})$ at $1,2,3,4,5,6,9,24,48$, and $72 \mathrm{~h}$ after the bolus, and serum radioactivity was determined by liquid scintillation counting.

In vivo production and clearance of labeled VLDL. To determine hepatic triglyceride production, three control and three high expressor HuAIVTg mice were anesthetized and treated with Triton WR 1339 $(500 \mathrm{mg} / \mathrm{kg}$ i.v.) to block lipolysis (45). Mice were then injected with $\left[{ }^{3} \mathrm{H}\right]$ glycerol ( $100 \mu \mathrm{Ci}$ i.v. $)$, and blood samples were obtained at 20,30 , 60,90 , and $120 \mathrm{~min}$ after the glycerol injection. The appearance of radioactivity in triglycerides was determined as described above (see "Intestinal triglyceride production").

For clearance studies, VLDL was labeled in vivo in control mice. Mice were injected intravenously with $\left[{ }^{3} \mathrm{H}\right]$ glycerol $(100 \mu \mathrm{Ci})$ and bled $30-45 \mathrm{~min}$ later. VLDL $(d<1.006 \mathrm{~g} / \mathrm{ml})$ was isolated by ultracentrifugation. About $90 \%$ of the radiolabeled material was associated with triglycerides as assessed by lipid extraction, thin-layer chromatography, and liquid scintillation counting.

Radiolabeled VLDL $\left(3 \times 10^{5} \mathrm{dpm} /\right.$ mouse $)$ clearance was determined in 11 control and 11 high expressor HuAIVTg mice. Recipient mice received an intravenous bolus of ${ }^{3} \mathrm{H}-\mathrm{VLDL}$, and were bled $(50 \mu \mathrm{l})$ at $2,5,10,20,40,75$, and $120 \mathrm{~min}$ for determination of serum radioactivity. VLDL triglyceride kinetics were analyzed using a single- or twopool model based on a main VLDL pool with the assumption that the remnant pool is derived entirely from the main pool. For each animal, the fitted curve was extrapolated back to time 0 to obtain the initial radioactivity.

Plasma lipid analysis. Blood was obtained from mice in the morning having had normal access to food (fed samples) and in the evening after they had fasted $8 \mathrm{~h}$ during the day (fasted samples). In some studies, serum $(200 \mu \mathrm{l})$ was separated by gel-filtration chromatography (Superose 6 FPLC; Pharmacia) and 1-ml fractions were analyzed as described below under apolipoprotein analysis. Total plasma triglycerides and cholesterol were determined enzymatically using commercial kits (no. 236691 and no. 126012, respectively; Boehringer Mannheim Corp., Indianapolis, IN). Lipoprotein triglyceride and cholesterol content were determined by on-line post-column analysis of Superose 6 gel-filtered 10-20 $\mu$ l plasma (48). For triglyceride analysis, blood was collected in the presence $0.8 \mathrm{mM}$ diethyl $p$-nitrophenyl phosphate (E600) (Sigma Chemical Co., St. Louis, MO) to inhibit circulating hepatic lipase.

Apolipoprotein analysis. Superose 6 gel-filtration chromatography fractions were concentrated, chemically reduced, and subject to $4-15 \%$ gradient SDS-PAGE (49). Gels were stained with Coomassie blue R-250.

Electronmicroscopy. To determine the size of VLDL particles, negative staining was performed with $2 \%$ potassium phosphotungstate $(\mathrm{pH}$ 7.6) followed by electron microscopy (50). VLDL was obtained from two control and two HuAIVTg mice. Both fasted and fed samples were studied. The average size of 150 particles in a given area was measured in each case.

Weight gain, food intake, and feeding behavior. Three groups of control $(n=5,20$, and 16) and high expressor HuAIVTg $(n=4,17$, and 7) female mice on chow diets were monitored for body weight once or twice a week between ages 12-20 wk.

Two approaches were used in the study of feeding behavior: in one, we examined the amount of chow eaten after a fast; in the other, we electronically monitored the circadian patterns of spontaneous feeding and drinking. In the first food intake experiment, six female control and six high expressor HuAIVTg mice were individually caged 2 wk before the initiation of the study. After an 18-h fast, the amount of chow eaten during the first hour was measured. This procedure was repeated on three separate occasions during a 4-wk period.

In another study, several weeks of spontaneous feeding behavior of six control and six high expressor HuAIVTg female mice was electronically monitored in 6-min intervals across the 12-12-h light-dark cycle. Licks of water and counts from a food hopper that could be triggered once a second by active gnawing at pelleted chow were used, in conjunction with amounts of water and chow consumed to calculate meal patterns $(51,52)$. For each mouse, data from three 24 -h periods were analyzed in terms of total food intake, number of meals (with a 12-min interval without ingestion defined as the end of meal), percent of feed-

A
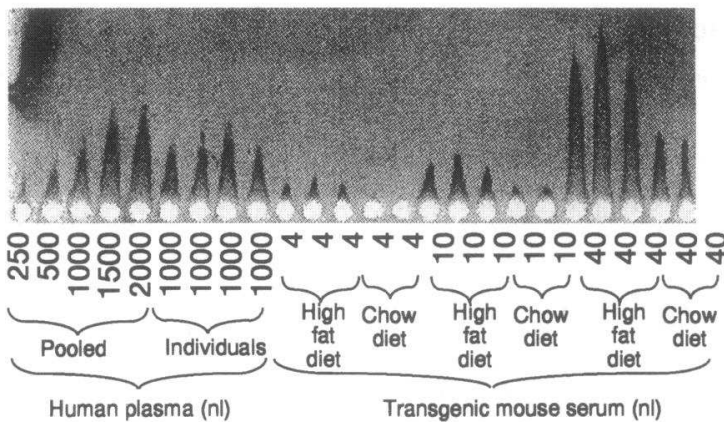

B

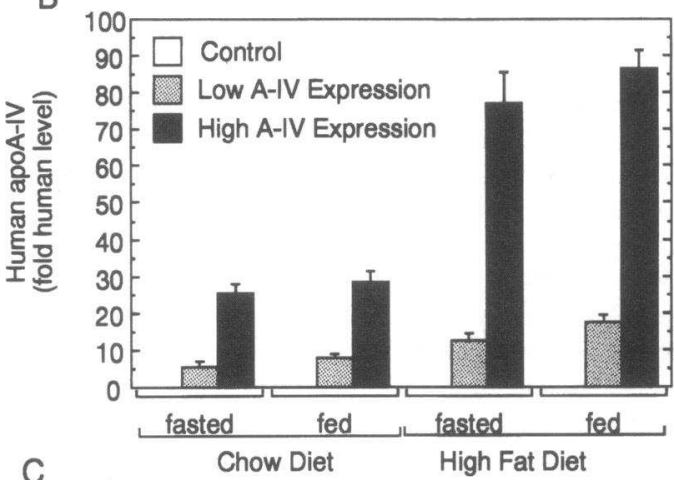

C

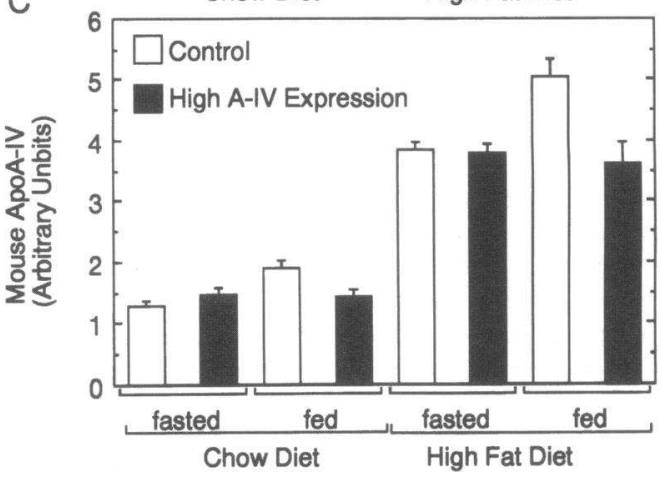

Figure 2. Apo A-IV levels in HuAIVTg mice. Human apo A-IV in mouse serum was quantitated by immunoelectrophoresis. Shown $(A)$ is a typical analysis of 4-40 $\mathrm{nl}$ of HuAIVTg mouse serum from animals maintained on either a high fat $(n=3)$ or chow $(n=2)$ diet (diluted serum from high expressor mice). A normalization standard $(0.25-2 \mu 1)$ prepared from pooled human plasma $(n=4)$ having an apo A-IV level of $19 \mathrm{mg} / \mathrm{dl}$ was included on all plates. Mouse serum apo A-IV was also quantitated by immunoelectrophoresis (not shown). Human $(B)$ and mouse $(C)$ apo A-IV levels \pm SE for control, low and high expressor mice are shown relative to the human plasma or a mouse plasma standard, respectively. 
ing and drinking in the light and dark portions of the light-dark cycle, and circadian patterns of feeding and drinking.

In an additional experiment, both food consumption by weight and electronically monitored feeding and drinking behavior were determined in another six control and six high expressor HuAIVTg mice during the first $30 \mathrm{~min}$ after a $24-\mathrm{h}$ fast. This procedure was repeated once.

Statistical analysis. Statistical examination of intestinal fat absorptions, as well as intestinal and hepatic triglyceride production were calculated using $t$ test for nonpaired samples. For VLDL turnover studies, statistical analysis was done by two-way ANOVA. Logarithms of triglycerides and fractional catabolic rate were used in statistical analyses to achieve similar variances in the groups. Statistical analysis was done with Statistical Analysis System (SAS Institute, Cary, NC).

For serum parameters (i.e., total and lipoprotein triglyceride and cholesterol and mouse and human apo A-IV levels), least squares means analysis (Superanova Version 1.11; Abacus Concepts, Inc., Berkeley, CA) was performed to determine significant differences between control, low, or high expressor HuAIVTg mice in either the fed or fasted state maintained on either chow or high fat diets.

Weight gain and various parameters of feeding behavior were examined by two-way repeated measures analysis of variance, where appropriate, or simple $t$ test between groups.

\section{Results}

Creation of human $A-I V$ transgenic mice. A human DNA fragment was constructed that extended from the PvuII site in the $5^{\prime}$ portion of the apo CIII gene to the HindIII site 3 ' to the apo A-IV gene. This included the intergenic region between the apo CIII and apo A-IV genes and the entire apo A-IV gene (Fig. 1). The DNA was microinjected into fertilized eggs. Two founder mice were born, which gave birth to healthy offspring expressing the human apo A-IV gene.

Plasma human and mouse apo A-IV levels. Human (Fig. 2 $A$ ) and mouse (not shown) apo A-IV levels were monitored by immunoelectrophoresis. When HuAIVTg mice derived from the two founders were maintained on a chow diet, their human apo A-IV levels were $\sim 6$ and 25 times the normal human level. These two HuAIVTg mouse lines were designated low and high expressors, respectively (Fig. 2 B). A high fat diet increased human apoA-IV serum levels to $\sim 12$ and 80 times the normal human level in the low and high expressor line, respectively (Fig. $2 B$ ). Gender did not significantly alter the human apo A-IV serum level (data not shown). Despite high human apo A-IV serum levels in the HuAIVTg mice maintained on a chow diet, mouse apo A-IV levels were not significantly different from those of control mice (Fig. $2 C$ ). Like human apo A-IV, about a threefold increase in mouse apo A-IV levels was observed when mice were maintained on the high fat diet. Mouse apo A-IV levels were significantly increased in fed compared to fasting conditions on chow and high fat diet in control mice $(P<0.03$ and 0.0001 , respectively) (Fig. $2 C$ ). In HuAIVTg mice, a similar but nonsignificant trend was observed in human apo A-IV levels (Fig. $2 \mathrm{~B}$ ).

Tissue expression of human and mouse apo A-IV. Mouse apoA-IV mRNA was expressed in the intestine, while human apoA-IV mRNA was found both in the intestine and, to a smaller extent, in the liver (Fig. 3). No expression of human or mouse apo A-IV mRNA in other tissues was detected (data not shown). High fat diet did not increase mouse or human apo A-IV mRNA.

Distribution of human apo A-IV in HuAIVTg mouse plasma. Pooled serum samples from control or high expressor HuAIVTg mice that were either fed or fasted, and on either chow or high fat diet, were separated by Superose 6 gel-filtration chromatography. Fractions were analyzed by SDS-PAGE (Fig. 4), and in some cases, human apo A-IV content by immunoelectrophoresis. By SDS-PAGE, we observed no major difference in the protein staining pattern across the profile, except, a $46-\mathrm{kD}$ protein was markedly increased at the elution volume of HDL and the lipoprotein-free fractions in the HuAIVTg profile. Immunoelectrophoresis of profile fractions demonstrated $55 \%$ of the human apo A-IV coeluted with HDL, while the remainder eluted in the lipoprotein-free fractions.

Intestinal lipid absorption. Intestinal lipid absorption was studied using a variety of models. First, we used a vitamin A-fat tolerance test, in which the serum concentrations with time of retinyl palmitate was determined after dosing of retinol in corn oil. Retinol is esterified in the intestine and secreted
A
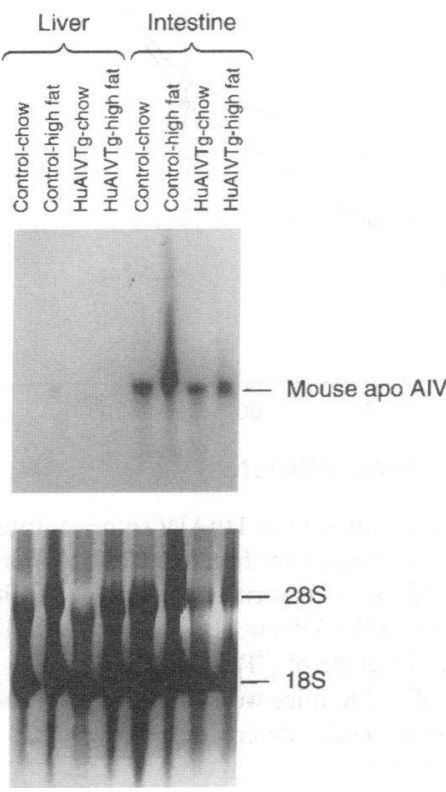

B

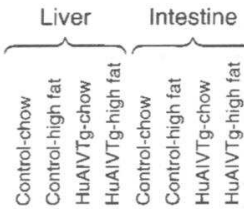

Human apo AIV

Figure 3. Northern blot analysis of liver and intestinal apo A-IV mRNA. RNA prepared from liver and intestine of control or HuAIVTg mice on chow or high fat diets was hybridized to mouse $(A)$ or human $(B)$ apo A-IV specific riboprobes. Lower panels show the respective ethidium bromide-stained gels. 


\section{A CONTROL}
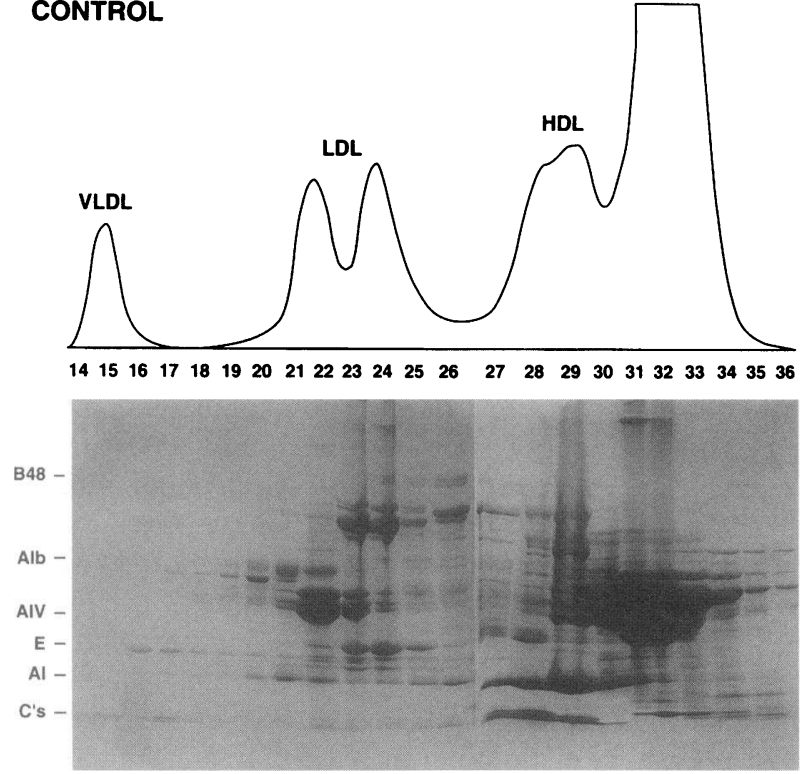

\section{B HuAIVTg}
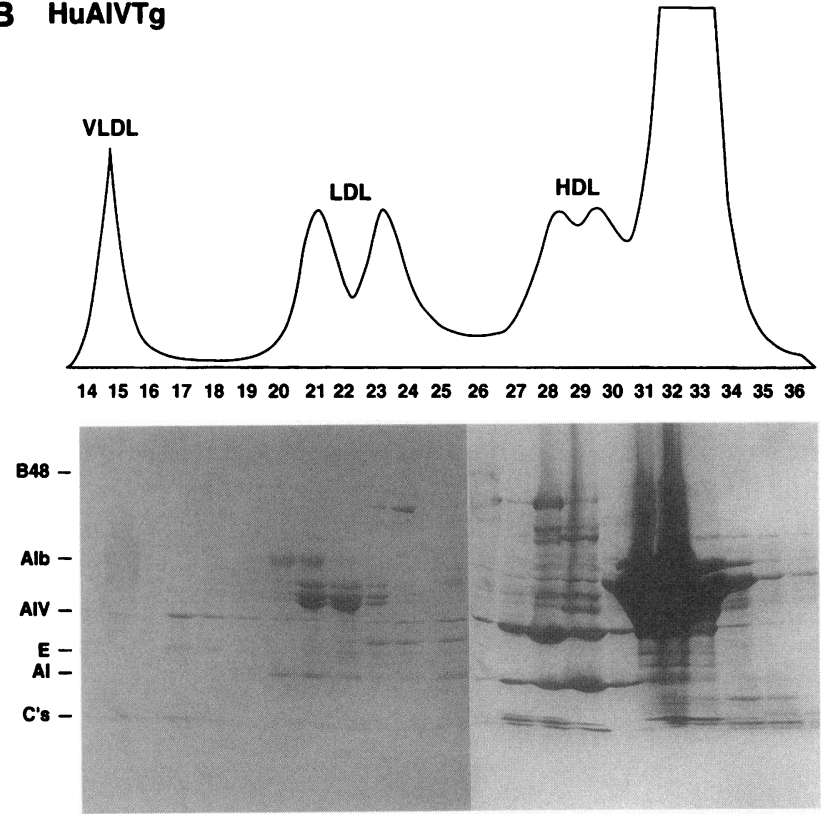

Figure 4. Fractionation of mouse plasma by Superose 6 chromatography. Pooled serum from fed control (A) or high expressor HuAIVTg $(B)$ mice on chow diets was chromatographed on Superose 6 by FPLC. Upper panels show OD 280 profile and indicate elution volumes of VLDL, LDL, and HDL. Aliquots of fractions were assessed for apo A-IV content (see Results) and protein by 4-15\% SDS-PAGE.

with chylomicrons. Once these particles are cleared, serum retinol, which is derived from the liver, is only found unesterified and bound to retinol binding protein (53). The appearance of retinyl palmitate in serum and its disappearance from chylomicron remnants was essentially identical in control and HuAIVTg mice (Fig. 5).

Second, triglyceride absorption in Triton WR 1339-treated mice was determined. Mice were given an intragastric bolus of glycerol- $\left[{ }^{3} \mathrm{H}\right]$ trioleate in corn oil, and the appearance rate of radiolabeled triglycerides in serum was determined. Again, we found no difference in the lipid absorption rates nor the incor-

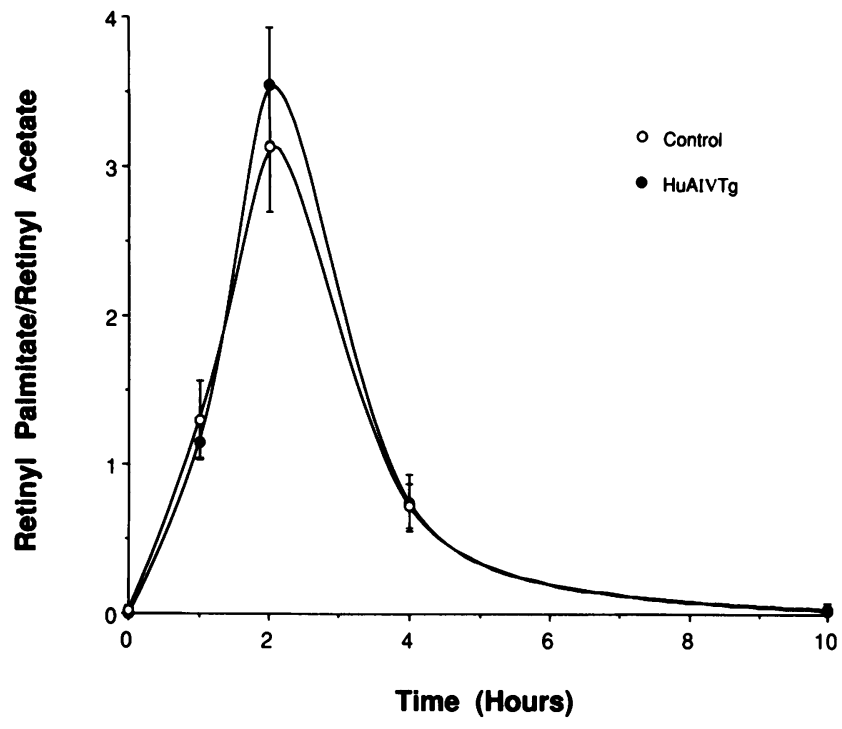

Figure 5. Vitamin A tolerance in HuAIVTg mice. Intestinal absorption of retinyl palmitate $(3,000 \mathrm{U}$ administered as an intragastric bolus in $100 \mu \mathrm{l}$ corn oil) was assessed in four control (O) and four high expression HuAIVTg $(\bullet)$ as described in Methods. At intervals up to $10 \mathrm{~h}$, mice were bled, and serum retinyl palmitate content relative to a retinyl acetate internal standard was determined. Data represent mean $\pm \mathrm{SD}$.

poration of glycerol into triglycerides between the control and transgenic mice (Fig. 6).

Next, we assessed intestinal cholesterol absorption using the double isotope method (47). Animals were dosed intragastrically with $\left[{ }^{14} \mathrm{C}\right]$ cholesterol and intravenously with $\left[{ }^{3} \mathrm{H}\right]$ -

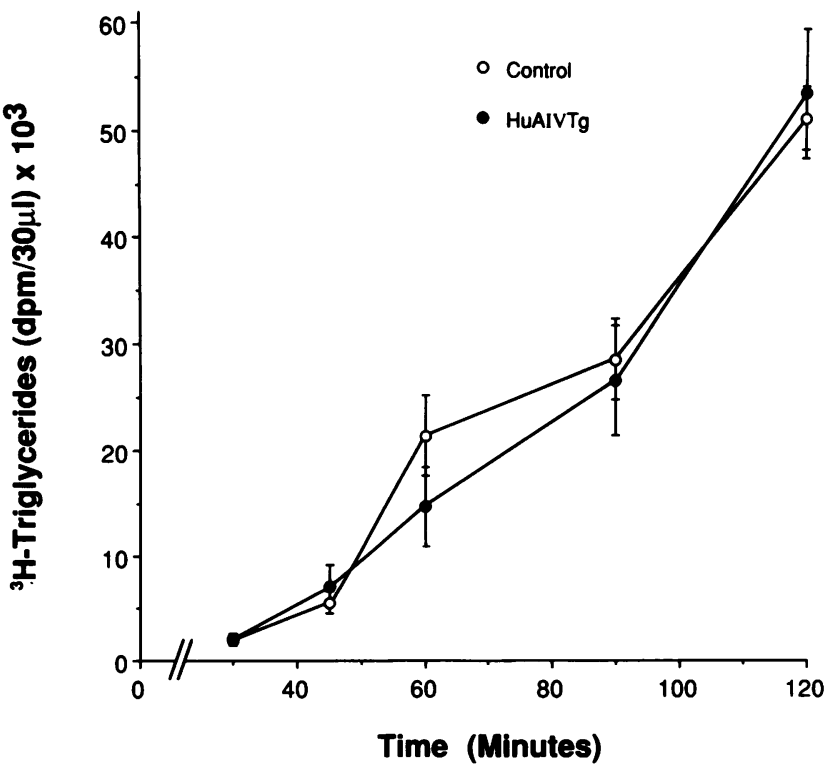

Figure 6. Intestinal triglyceride production in HuAIVTg mice. Intestinal triglyceride production was assessed in three control $(0)$ and three high expression HuAIVTg $(\bullet)$ as described in Methods. Mice were initially treated with Triton WR 1339 (to block lipolysis) and then given an intragatric bolus of glycerol $\left[{ }^{3} \mathrm{H}\right]$ trioleate $(50 \mu \mathrm{Ci})$ in corn oil $(100 \mu \mathrm{l})$. At intervals of $\leq 2 \mathrm{~h}$, mice were bled and radioactivity associated with plasma triglycerides determined as described in Methods. Data represent mean \pm SD. 
cholesterol. At $\sim 24 \mathrm{~h}$, both isotopes were cleared from serum at the same rate (data not shown). The isotope ratio $\left({ }^{14} \mathrm{C} /{ }^{3} \mathrm{H}\right.$ ) was therefore determined at four time points after $24 \mathrm{~h}$ to assess cholesterol absorption. The average of these determinations was regarded as the amount of cholesterol absorbed for each animal. Based on the ${ }^{14} \mathrm{C} /{ }^{3} \mathrm{H}$ ratio, the amount cholesterol absorbed was essentially identical in control and HuAIVTg mice (67.7 \pm 4.0 and $68.5 \pm 4.7 \%$, respectively).

Last, we assessed intestinal $\left[{ }^{14} \mathrm{C}\right] \alpha$-tocopherol (vitamin E) absorption. Although both vitamins $A$ and $E$ passing through the intestine are absorbed and secreted in chylomicrons, hepatic vitamin $\mathrm{E}$, unlike vitamin $\mathrm{A}$, is transported in lipoproteins. Further, $\alpha$-tocopherol is specifically incorporated into VLDL for secretion by the liver into the plasma (reviewed in reference 54). After an intragastric bolus, radioactive enrichment of chylomicrons was observed during 2-6 $\mathrm{h}$ in both control and HuAIVTg mice (Fig. 7). Chylomicron vitamin E was not statistically different between the groups. A second peak, corresponding to radiolabeled vitamin E carried in VLDL, was detected $\sim 24 \mathrm{~h}$ after the animals received the label. This peak was significantly higher $(P<0.05)$ in HuAIVTg mice than in controls (Fig. 7). By $48 \mathrm{~h}$, radiolabeled vitamin $\mathrm{E}$ in the serum of control and HuAIVTg mice converged.

Overall, intestinal absorption of triglycerides, cholesterol, or fat-soluble vitamins was the same in HuAIVTg and control mice. Chylomicron metabolism, as assessed by retinyl palmitate clearance, was normal. However, the vitamin E clearance data suggest an altered VLDL metabolism in the HuAIVTg mice.

$V L D L$ metabolism in the HuAIVTg mice. Hepatic VLDL triglyceride production was studied in Triton WR 1339treated mice. No significant differences were observed in the appearance of radiolabeled triglycerides in serum of control and high expressor HuAIVTg mice (Fig. 8).

VLDL clearance was studied using VLDL radiolabeled in vivo (from donor mice) as described in Methods. The major VLDL metabolic difference between control and HuAIVTg mice was that the disappearance of radiolabeled VLDL was significantly diminished in the high expressor HuAIVTg com-

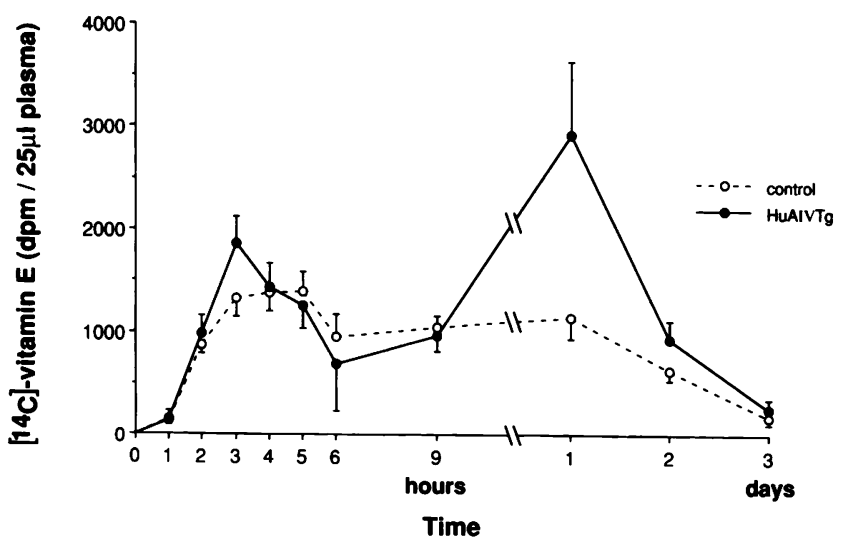

Figure 7. Intestinal vitamin E absorption in HuAIVTg mice. Intestinal absorption of vitamin $\mathrm{E}$ ( $10 \mu \mathrm{Ci}$ administered as an intragastric bolus in $100 \mu \mathrm{l}$ corn oil) was assessed in eight control $(O)$ and seven high expression HuAIVTg $(\bullet)$ as described in Methods. Serum vita$\min \mathrm{E}$ radioactivity was determined at intervals of $\leq 72 \mathrm{~h}$. Data represent mean $\pm \mathrm{SD}$.

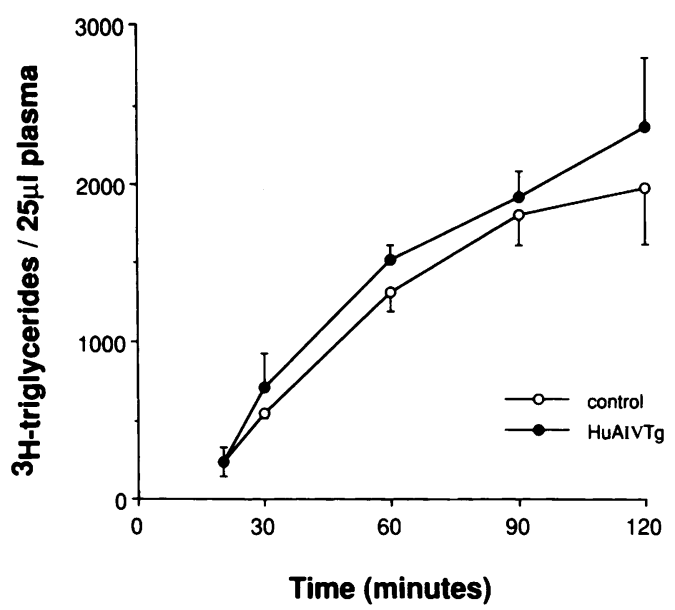

Figure 8. Hepatic triglyceride production in HuAIVTg mice. Hepatic triglyceride production was assessed in three control $(O)$ and three high expression HuAIVTg $(\bullet)$ as described in Methods. Mice were treated with Triton WR 1339 (to block lipolysis) and then intravenously injected with $\left[{ }^{3} \mathrm{H}\right]$ glycerol $(100 \mu \mathrm{Ci})$. Serum triglyceride radioactivity was determined $\leq 2 \mathrm{~h}$ after the $\left[{ }^{3} \mathrm{H}\right]$ glycerol injection. Data represent mean \pm SD.

pared to controls $(3.3+2.3$ vs $10.1+5.8$ pools $/ \mathrm{h}$, respectively, $P<0.0001$ ) (Fig. 9, Table I). Clearance in control mice was consistent with a two-pool model, and included a rapidly and slowly removed VLDL pool. In contrast, VLDL clearance in 9 out of 11 HuAIVTg mice conformed to a single-pool model.

Serum lipids and lipoproteins. Serum lipid and lipoprotein levels in control, low, and high expressor HuAIVTg mice are presented in Table II. Apo A-IV overexpression did not significantly change serum total cholesterol levels in the fasted condition when mice were maintained on either chow or high fat diets ( Table II ). In the fed state on the chow diet, plasma choles-

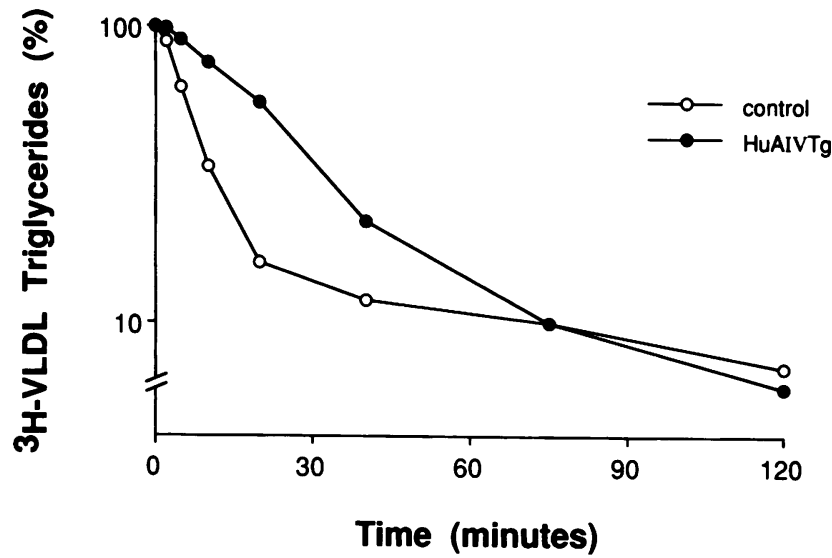

Figure 9. VLDL clearance in HuAIVTg mice. VLDL clearance in mice was studied in 11 control $(O)$ and 11 high expression HuAIVTg $(\bullet)$ using ${ }^{3} \mathrm{H}$-triglyceride VLDL isolated from donor mice as described in Methods. ${ }^{3} \mathrm{H}$-triglyceride VLDL $\left(3 \times 10^{5} \mathrm{dpm} / \mathrm{mouse}\right)$ was intravenously administered to mice, and serum radioactivity was determined at intervals of $\leq 2 \mathrm{~h}$. Representative decay curves for labeled VLDL triglycerides in a control and a HuAIVTg mouse is shown. Data from all mice studied were used to determine triglyceride fractional catabolic rate and production rate, and they are shown in $\mathrm{Ta}$ ble I. 
Table I. VLDL Triglycerides Fractional Catabolic Rates (FCR) and Production Rates (PR) for Control and High Expressor HuAIVTg Mice

\begin{tabular}{lccccc}
\hline & $n$ & Weight & Triglycerides & FCR & PR \\
\hline & & $g$ & $m g / d l$ & $p o o l / h$ & $m g / h / g$ \\
Control & 11 & $24 \pm 2^{*}$ & $111 \pm 33$ & $10.1 \pm 5.8$ & $0.36 \pm 0.24$ \\
HuAIVTg & 11 & $23 \pm 5$ & $228 \pm 77$ & $3.3 \pm 2.3$ & $0.22 \pm 0.12$ \\
$P$ & & NS & 0.0001 & 0.0001 & 0.03 \\
& & & & & \\
\hline
\end{tabular}

* Mean \pm SD.

terol levels did not differ significantly from each other; however, on the high fat diet in the high expressor mice, total cholesterol was significantly elevated compared to the controls ( $P$ $<0.0001)$ or the low expressor mice $(P<0.001)$ (Table II). Further analysis of the plasma lipoproteins in high expressor mice revealed this increase was largely caused by a marked elevation of VLDL cholesterol $(P<0.0001)$ and diminution in HDL cholesterol $(P<0.0001)$ (Fig. 10, Table II). Similar significant changes in VLDL and HDL cholesterol levels were also found when the mice were kept on chow diet (Fig. 10, Table II ). In the fed state, a similar trend for VLDL cholesterol elevation was seen in some of the low expressor HuAIVTg mice (data not shown). However, the variability between animals resulted in no significant differences for VLDL cholesterol for mice maintained on chow $(P=0.09)$ or high fat $(P$ $=0.75$ ) diets (Table II).

Plasma triglycerides in the fasted condition were not significantly different between control, low expressor, or high expressor HuAIVTg mice maintained on either diet regimen (Table II). In contrast, in the fed condition on the chow diet, plasma triglycerides were significantly elevated in both low $(P<0.001)$ and high expressor $(P<0.0001)$ HuAIVTg mice (Table II). This effect was mainly caused by a marked elevation in VLDL triglycerides in the HuAIVTg mice. In the fed state on the high fat diet, a significant increase in plasma triglycerides was seen only in high expressor HuAIVTg mice $(P<0.0001)$ ( Table II ).

VLDL size was determined by negative staining electronmicroscopy. Neither average diameter nor size distribution of VLDL were significantly different between control and HuAIVTg VLDL (data not shown).
Weight gain, food intake and feeding behavior in HuAIVTg mice. Weight gain was monitored in three separate groups of control and high expressor HuAIVTg mice. No significant difference in the rate or amount of weight gain was observed between the control and HuAIVTg mice (Fig. 11). Food intake was determined by the amount of chow consumed during the first hour of dark in the light-dark cycle after an 18-h fast in six control and six HuAIVTg females. The experiment was repeated for a total of four separate occasions during a 4-wk period. Initial body weight of 8-wk-old control $(26.0 \pm 3.0 \mathrm{~g})$ compared to high expressor HuAIVTg $(26.6 \pm 1.2 \mathrm{~g})$ mice used in these experiments were not significantly different. Food consumption was not significantly different in control $(0.781 \pm 0.237 \mathrm{~g} / \mathrm{h})$ when compared to HuAIVTg $(0.808 \pm 0.280$ $\mathrm{g} / \mathrm{h}$ ) mice. Electronically monitored gnawing and licking time were also determined in six control and six HuAIVTg female mice that had been acclimated to their cages. The feeding and drinking pattern did not show any significant differences between the groups (Fig. 12). Also the diurnal feeding habits, as determined by the size and number of meals in dark and in light and the percentage of food eaten in light and dark, were not significantly different between the groups (Table III). In two separate experiments, food consumption (mean \pm SD) was monitored during the first half hour after a $24-\mathrm{h}$ fast in control $(27.0 \pm 1.8 \mathrm{~g})$ and HuAIVTg $(27.1 \pm 1.1 \mathrm{~g})$ mice. Again, we found no difference in the amount of food consumed by control $(1.010 \pm 0.406 \mathrm{~g} / 30 \mathrm{~min})$ and HuAIVTg $(0.893 \pm 0.249$ $\mathrm{g} / 30 \mathrm{~min}$ ) mice.

\section{Discussion}

In the present study, we have created mice that express human apo A-IV to help understand apo A-IV function. In similar types of studies, overexpression of other apolipoproteins has provided new knowledge of their physiologic role $(36,45,55-$ 60 ). In the case of apo A-IV, this approach is particularly needed, since many functions of apo A-IV have been suggested based on circumstantial evidence and in vitro studies, but none of these have been proven to be unique and important in vivo. We analyzed two transgenic lines, a low and a high expressor line. These two lines express mainly intestinal but also some hepatic human apo A-IV mRNA, and this results in circulating levels $\sim 6$ and 25 times the normal human level, respectively, on a chow diet. A high fat diet elevated human apo A-IV to

Table II. Serum Lipid and Lipoproteins Levels in Control and Low and High Expressor HuAIVTg Mice (mean \pm SD)

\begin{tabular}{|c|c|c|c|c|c|c|c|c|c|c|c|c|c|c|c|}
\hline & \multirow[b]{2}{*}{$n$} & \multicolumn{2}{|c|}{ Fast chow } & \multicolumn{2}{|c|}{ High fat } & \multicolumn{5}{|c|}{ Fed chow } & \multicolumn{5}{|c|}{ High fat } \\
\hline & & C & TG & $\mathrm{C}$ & TG & $\mathrm{C}$ & TG & VLDL-C & VLDL-TG & HDL-C & $\mathrm{C}$ & TG & VLDL-C & VDL-TG & HDL-C \\
\hline $\begin{array}{l}\text { Control } \\
\text { Low expressor }\end{array}$ & 22 & $76 \pm 3$ & $98 \pm 6$ & $134 \pm 7$ & $109 \pm 8$ & $84 \pm 3$ & $215 \pm 16$ & $12 \pm 1$ & $165 \pm 17^{*}$ & $59 \pm 3$ & $170 \pm 6$ & $212 \pm 16$ & $17 \pm 2$ & $164 \pm 19^{*}$ & $127 \pm 7$ \\
\hline $\begin{array}{c}\text { Low expressor } \\
\text { HuAIVTg }\end{array}$ & 10 & $70 \pm 7$ & $85 \pm 5$ & $133 \pm 12$ & $95 \pm 10$ & $99 \pm 7$ & $356 \pm 6$ & $23 \pm 6$ & $265 \pm 53$ & $56 \pm 3$ & $181 \pm 10$ & $215 \pm 19$ & $19 \pm 4$ & $170 \pm 20$ & $149 \pm 8$ \\
\hline $\begin{array}{l}\text { High expressor } \\
\text { HuAIVTg } \\
P\end{array}$ & 12 & $74 \pm 5$ & $133 \pm 15$ & $146 \pm 11^{\ddagger}$ & $110 \pm 12^{\ddagger}$ & $91 \pm 6$ & $496 \pm 54$ & $52 \pm 6$ & $538 \pm 82^{\S}$ & $34 \pm 2$ & $224 \pm 18^{\ddagger}$ & $651 \pm 107^{\ddagger}$ & $120 \pm 17$ & $772 \pm 182^{11}$ & $83 \pm 2$ \\
\hline $\begin{array}{l}\text { Control vs low } \\
\text { Control vs high } \\
\text { Low vs high }\end{array}$ & & $\begin{array}{l}\text { NS } \\
\text { NS } \\
\text { NS }\end{array}$ & $\begin{array}{l}\text { NS } \\
\text { NS } \\
\text { NS }\end{array}$ & $\begin{array}{l}\text { NS } \\
\text { NS } \\
\text { NS }\end{array}$ & $\begin{array}{l}\text { NS } \\
\text { NS } \\
\text { NS }\end{array}$ & $\begin{array}{l}\text { NS } \\
\text { NS } \\
\text { NS }\end{array}$ & $\begin{array}{l}0.001 \\
0.0001 \\
0.003\end{array}$ & $\begin{array}{l}0.1 \\
0.0001 \\
0.0001\end{array}$ & $\begin{array}{l}0.04 \\
0.0001 \\
0.0001\end{array}$ & $\begin{array}{l}\text { NS } \\
0.001 \\
0.01\end{array}$ & $\begin{array}{c}\text { NS } \\
0.0001 \\
0.0001\end{array}$ & $\begin{array}{c}\text { NS } \\
0.0001 \\
0.0001\end{array}$ & $\begin{array}{c}\text { NS } \\
0.0001 \\
0.0001\end{array}$ & $\begin{array}{c}\text { NS } \\
0.0001 \\
0.0001\end{array}$ & $\begin{array}{c}\text { NS } \\
0.0001 \\
0.0001\end{array}$ \\
\hline
\end{tabular}

${ }^{*} n=16,{ }^{\ddagger} n=9,{ }^{\S} n=6, " ~ n=4$.

TC, total cholesterol; TG, triglycerides; C, cholesterol. 


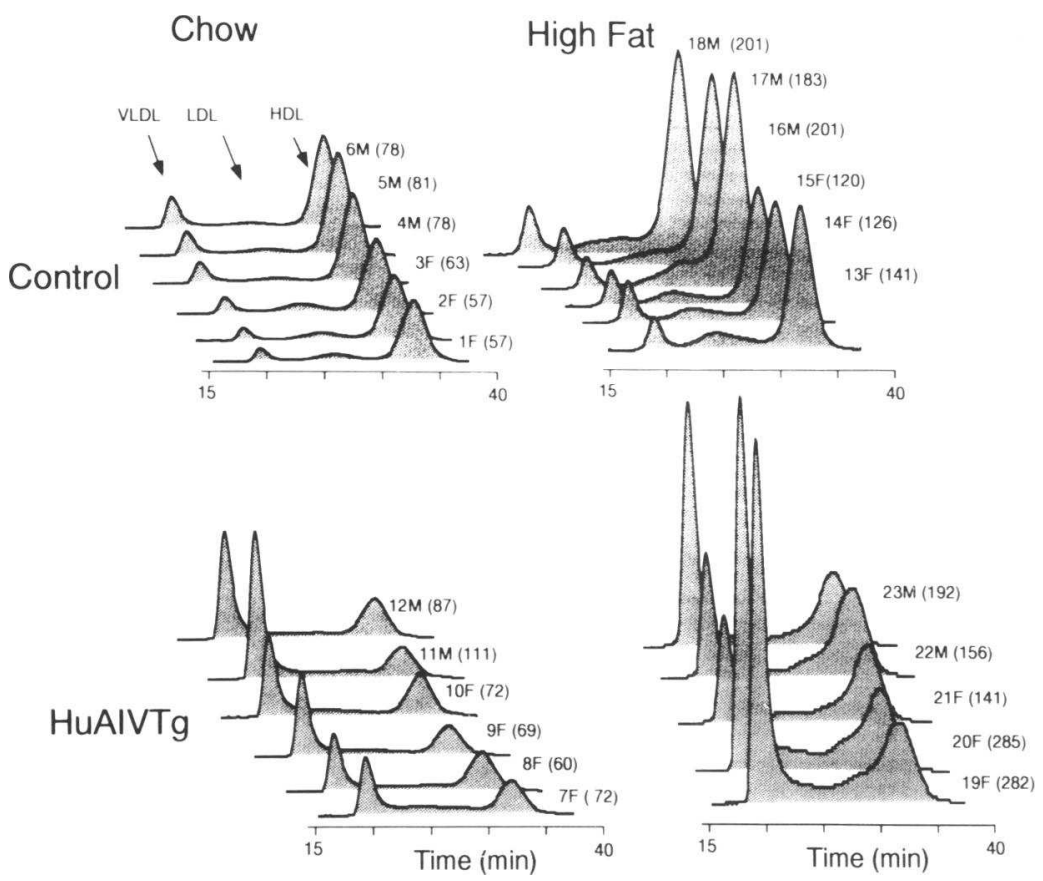

Figure 10. Lipoprotein total cholesterol profile by high pressure gel filtration chromatography in fed control and high expressor HuAIVTg mice. Total lipoprotein cholesterol profiles were determined by online post-column analysis of Superose 6 gel-filtered mouse serum (10-20 $\mu \mathrm{l})$. Plasma from fed control (mice 1-6) and high expressor HuAIVTg (mice 7-12) mice on chow diets and control (mice 13-18) and high expressor HuAIVTg (mice 19-23) mice on high fat diets were analyzed. Mice are identified by numbers 1-23 next to each serum profile. Gender ( $M$ or F), and total cholesterol in milligrams per deciliter are indicated (in parentheses). These analyses were performed on a Beckman-Gold system (48). Lipoprotein cholesterol distribution was determined from percent area distribution in profiles and from independent cholesterol determinations (in whole serum). All the profiles are in the same scale. Serum triglyceride distributions were determined by similar methods (profiles not shown) and from independent triglyceride determinations (in whole serum). Table III summarizes lipoprotein cholesterol and triglyceride data from all mice. $\sim 12$ and 80 times the normal human level, respectively. Mouse apo A-IV levels were similar in control and HuAIVTg mice, and rose if the mice were maintained on a high fat diet. In HuAIVTg mice, human apo A-IV levels paralleled those of mouse apo A-IV in response to lipid feeding. It thus seems that mouse and human apo A-IV levels are controlled by the same regulatory elements. Since neither mouse or human apo A-IV mRNA was increased by high fat diet, this regulation is posttranscriptional and it does not distinguish between mouse and human apo A-IV proteins. Despite the high circulating human

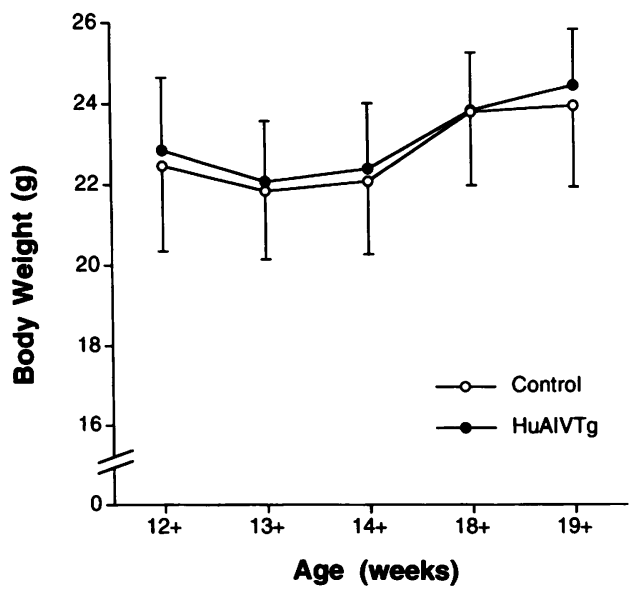

Figure 11. Weight gain in control and high expressor HuAIVTg mice. Weight gain was monitored in three separate groups of control ( 5 , 20, and 16 mice/group) and high expressor HuAIVTg (4, 17, and 7 mice/group) mice once or twice a week between weeks 12 and 20 of age. The weight measurements for a mouse within a week were pooled to give a single measure per week for each mouse; i.e., the mean of the weight at 12 and $12.5 \mathrm{wk}=12+$. The mice had free access to chow diet. Curves represent pooled data from the three groups of control and HuAIVTg mice. Data presented as mean \pm SE. apo A-IV levels, we found approximately half of it associated with lipoproteins (mainly HDL) with the remainder in the lipoprotein-free fraction. This distribution is analogous to that found in the plasma of rats (31).

Apo A-IV is thought to play a role in lipid absorption; thus we assessed a number of parameters of lipid absorption in the HuAIVTg mice. We found essentially no difference in triglyceride, cholesterol, vitamin A, or vitamin E absorption. Thus, it seems that elevated amounts of apo A-IV do not have any major effect on normal lipid absorption in this model system. In addition to lipid absorption, chylomicron clearance was normal. We did note that HuAIVTg mice maintained on either a chow or a high fat diet had a sustained elevation of VLDL triglycerides and cholesterol. This elevation was more prominent in the high expressor HuAIVTg mice. This finding would be consistent with either an increased VLDL production or a delayed clearance. VLDL production was essentially identical in control and HuAIVTg mice as determined by the appearance of newly synthesized radiolabeled triglycerides in Triton WR 1339-treated mice, thus suggesting a delayed clearance. Fractional catabolic rate determinations with in vivo-labeled VLDL confirmed a diminished VLDL clearance. This result was somewhat surprising, in that this effect seemed specific for VLDL clearance, but not chylomicron clearance. It is possible that the abnormally high hepatic expression of human apo AIV in these transgenic mice alters the protein composition of newly secreted VLDL particles. Hepatic apo A-IV could either replace or mask other VLDL apolipoproteins. Possibly, in these mice the marked elevation of apo A-IV might displace or mask apo E on VLDL (but not chylomicron) resulting in a delayed clearance. The specificity of this process for VLDL but not chylomicrons may simply be related to their marked difference in surface area and curvature. In this regard, apo A-IV has been shown to displace apo $\mathrm{E}$ from the surface of liposomes in a concentration dependent manner (32). The kinetic analysis of VLDL clearance in HuAIVTg mice showed mainly one re- 

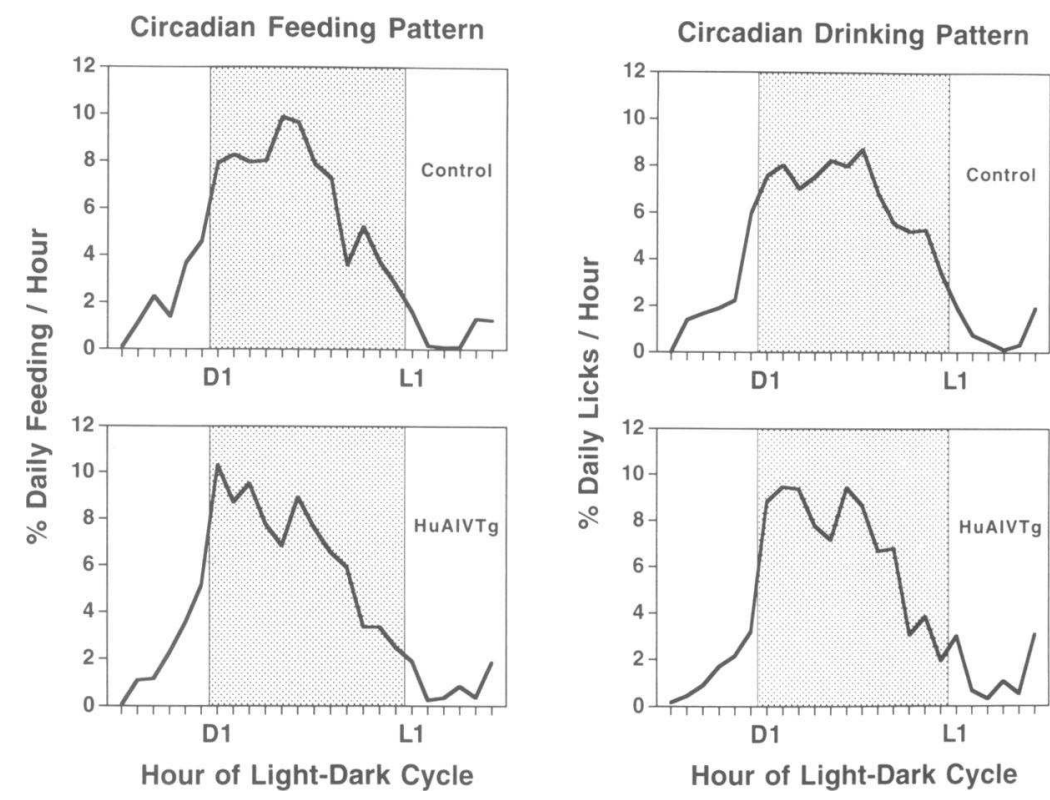

Figure 12. Feeding behavior in HuAIVTg mice. The pooled circadian feeding and drinking patterns of six control and six high expressor HuAIVTg mice were monitored using electronically fitted food hoppers and water bottles as described in Methods. Data represents percentage of daily time spent gnawing at pelleted chow and percentage of daily licks in each hour of the 12-12-hour light-dark cycle. The means of three 24-h d over a 2-wk interval were calculated for each mouse. Data were collected as described in Methods. The shaded area represents the dark period. $D 1$, first hour at dark; $L 1$, first hour at light.

moved pool whereas in control mice slow and fast removed pools were detected. The rate of VLDL removal in HuAIVTg mice was between the rates for the fast and slow removed pools in the control mice.

Studies on the transport of vitamin E in these transgenic mice also provided the clue that VLDL turnover might be altered. In humans (61-63), monkeys (64) and rats (65), RRR$\alpha$-tocopherol is preferentially transported in plasma. Studies using perfused monkey livers demonstrated that RRR- $\alpha$ tocopherol is preferentially secreted in nascent VLDL (54). This process is likely under the control of a hepatic tocopherol binding protein $(66,67)$. Vitamin $E$ transport is a two-step process, first transported in chylomicrons and then packaged in VLDL. The transport in chylomicrons was similar in control and $\mathrm{HuAIVTg}$ mice, but the transport in VLDL was abnormally increased in HuAIVTg mice. This provides separate evidence that increased hepatic production of apo A-IV decreases VLDL fractional catabolic rate.

Table III. Weight Gain, Food Consumption, and Electronically Monitored Feeding Behavior in Chow-fed Female HuAIVTg

\begin{tabular}{lccc}
\hline & $\begin{array}{c}\text { Control } \\
(n=6)\end{array}$ & $\begin{array}{c}\text { HuAIVTg } \\
(n=6)\end{array}$ & $P$ \\
\hline Animal weight (g) & & & \\
$\quad$ Day 1 & $22.1 \pm 0.4^{*}$ & $23.6 \pm 0.3$ & NS \\
$\quad$ Day 21 & $23.0 \pm 0.4$ & $23.2 \pm 0.7$ & NS \\
$\begin{array}{l}\text { Food consumed/d (g) } \\
\text { Day 1 }\end{array}$ & $4.3 \pm 0.1$ & $4.1 \pm 0.1$ & NS \\
$\quad$ Day 21 & $5.0 \pm 0.1$ & $4.7 \pm 0.2$ & NS \\
Number of meals & & & \\
$\quad$ Dark cycle & $3.2 \pm 0.5$ & $4.8 \pm 1.5$ & NS \\
$\quad$ Light cycle & $3.7 \pm 0.3$ & $3.5 \pm 0.2$ & NS \\
Percent of food consumed & & & \\
$\quad$ In dark cycle & $82.3 \pm 2.8$ & $81.3 \pm 4.9$ & NS \\
$\quad$ In light cycle & $17.7 \pm 2.8$ & $18.7 \pm 4.9$ & NS \\
& & & \\
\hline
\end{tabular}

${ }^{*}$ Mean \pm SE.
Thus, in these mice, delayed VLDL clearance was the only apparent lipoprotein abnormality causing triglycerides and cholesterol to be elevated in nonfasted animals. Most likely, however, this does not appear to be a physiological function of apo A-IV, since the elevation of apo A-IV in these mice was so huge. We speculate that this effect is likely caused by an apo A-IV displacement of VLDL apo E (34) allowing the lipoprotein to persist in plasma $(56,58,68)$. Even though the total amount of apo E in VLDL seemed to be normal in HuAIVTg mice, the amount of apo E per VLDL was decreased, since the number of VLDL particles in HuAIVTg mice was increased.

About half of human apo A-IV in HuAIVTg mice was found bound to HDL particles. However, plasma HDL cholesterol was decreased in these mice. Fast protein liquid chromatography demonstrated an increased amount of large HDL particles in HuAIVTg mice. SDS-PAGE suggested that these large HDL particles are more enriched with human apo A-IV than the smaller HDL particles. The reason for decreased HDL cholesterol in these HuAIVTg mice is still to be determined. The large amount of apo A-IV associated with HDL may represent apolipoprotein-apolipoprotein interactions (i.e., homoor heteroaggregates) $(69,70)$.

Recent studies in rats by Fujimoto and his co-workers have suggested rat apoA-IV acts as a satiety factor $(28,29)$. They showed that rat apo A-IV administered intravenously or into the third ventricle significantly reduced food consumption by fasted rats when allowed access to a meal. Thus, it was surprising to find that in our studies, HuAIVTg mice gained weight normally and their feeding behavior was completely normal. The differences between Fujimoto's study and the current studies may result since transgenic mice with chronically elevated apo A-IV levels could have adapted to the high apo A-IV levels and only apo A-IV above this baseline would act as a satiety factor to them. In this regard, in the high expressor HuAIVTg mice a similar increase in their apo A-IV level is seen postprandially as in control mice. It could be that this increase in apo A-IV acts as a satiety factor in both control and HuAIVTg mice. Alternatively, the lack of an effect on satiety in the HuAIVTg mice may be the result of a response unique to rodent apo A-IV but not human apo A-IV. Thus, species-specific 
differences may determine whether this apolipoprotein effects feeding behavior, although this possibility has not been tested directly in the rat. It is also possible that human apo A-IV does not cross the blood-brain barrier in mice, since apo A-IV was claimed to act in the central nervous system in rats (29).

Our studies with transgenic mice expressing huge amounts of human apo A-IV demonstrated that additional plasma apo A-IV has little effect on most normal lipid metabolism and feeding behavior in mice. It is possible that endogenous mouse apo A-IV is sufficient to carry out all physiological functions of this protein, and insights into apo A-IV function will only be revealed by studying animal models lacking this protein, such as a mouse in which the gene has been knocked out.

\section{Acknowledgments}

This work was supported by grants from the National Institute of Health (HL-32435-09 and HL-33714-08) and a fund from the Finnish Heart Foundation.

\section{References}

1. Elshourbagy, N. A., D. W. Walker, M. S. Boguski, J. I. Gordon, and J. M. Taylor. 1986. The nucleotide and derived amino acid sequence of human apolipoprotein A-IV mRNA and the close linkage of its gene to the genes of apolipoproteins A-I and C-III. J. Biol. Chem. 261:1998-2002.

2. Utermann, G., and U. Beisiegel. 1979. Apolipoprotein A-IV: a protein occurring in human mesenteric lymph chylomicrons and free in plasma. Isolation and quantification. Eur. J. Biochem. 99:333-343.

3. Green, P. H. R., R. M. Glickman, J. W. Riley, and E. Quinet. 1980. Human apolipoprotein A-IV. Intestinal origin and distribution in plasma. J. Clin. Invest. 65:911-919.

4. Weinberg, R. B., and A. M. Scanu. 1983. Isolation and characterization of human apolipoprotein A-IV from lipoprotein-depleted serum. J. Lipid Res. 24:52-59.

5. Lefevre, M., and P. S. Roheim. 1984. Metabolism of apolipoprotein A-IV. J. Lipid Res. 25:1603-1610.

6. Bisgaier, C. L., O. P. Sachdev, L. Megna, and R. M. Glickman. 1985. Distribution of apolipoprotein A-IV in human plasma. J. Lipid Res. 26:11-25.

7. Ghiselli, G., S. Krishnan, Y. Beigel, and A. M. Gotto, Jr. 1986. Plasma metabolism of apolipoprotein A-IV in humans. J. Lipid Res. 27:813-827.

8. Karathanasis, S. K., I. Yunis, and V. I. Zannis. 1986. Structure, evolution, and tissue-specific synthesis of human apolipoprotein A-IV. Biochemistry. 25:3962-3970.

9. Bisgaier, C. L., O. P. Sachdev, E. S. Lee, K. J. Williams, C. B. Blum, and R. M. Glickman. 1987. Effect of lecithin:cholesterol acyltransferase on distribution of apolipoprotein A-IV among lipoproteins of human plasma. J. Lipid Res. 28:693-703.

10. Lagrost, L., P. Gambert, S. Meunier, P. Morgado, J. Desgres, P. d'Athis, and C. Lallemant. 1989. Correlation between apolipoprotein A-IV and triglyceride concentrations in human sera. J. Lipid Res. 30:701-710.

11. Elshourbagy, N. A., M. S. Boguski, W. S. L. Liao, L. S. Jefferson, J. I. Gordon, and J. M. Taylor. 1985. Expression of rat apolipoprotein A-IV and A-I genes: mRNA induction during development and in response to glucocorticoids and insulin. Proc. Natl. Acad. Sci. USA. 82:8242-8246.

12. Elshourbagy, N. A., D. W. Walker, Y.-K. Paik, M. S. Boguski, M. Freeman, J. I. Gordon, and J. M. Taylor. 1987. Structure and expression of the human apolipoprotein A-IV gene. J. Biol. Chem. 262:7973-7981.

13. Karathanasis, S. K. 1985. Apolipoprotein multigene family: tandem organization of human apolipoprotein AI, CIII, and AIV genes. Proc. Natl. Acad. Sci. USA. 82:6374-6378.

14. Karathanasis, S. K., P. Oettgen, I. A. Haddad, and S. Antonarakis. 1986. Structure, evolution and polymorphisms of the human apolipoprotein A4 gene (APOA4). Proc. Natl. Acad. Sci. USA. 83:8457-8461.

15. Walsh, A., N. Azrolan, K. Wang, A. Marcigliano, A. O'Connell, and J. L. Breslow. 1993. Intestinal expression of the human apoA-I gene in transgenic mice is controlled by a DNA region $3^{\prime}$ to the gene in the promoter of the adjacent convergently transcribed apoC-III gene. J. Lipid Res. 34:617-623.

16. Green, P. H. R., J. H. Lef kowitch, R. M. Glickman, J. W. Riley, E Quinet, and C. B. Blum. 1982. A polipoprotein localization and quantitation in the human intestine. Gastroenterology. 83:1223-30.

17. DeLamatre, J. G., and P. S. Roheim. 1983. The response of apolipoprotein A-IV to cholesterol feeding in rats. Biochim. Biophys. Acta. 751:210-217.

18. Apfelbaum, T. F., N. O. Davidson, and R. M. Glickman. 1987. Apolipo- protein A-IV synthesis in rat small intestine: regulation by dietary triglyceride and biliary lipid. Am. J. Physiol. 252:G662-G666.

19. Seishima, M., A. Noma, H. Torizawa, and Y. Muto. 1988. Changes of serum apolipoprotein levels after oral administration of fat in human subjects. Atherosclerosis. 73:39-43.

20. Sherman, J. R., and R. B. Weinberg. 1988. Serum apolipoprotein A-IV and lipoprotein cholesterol in patients undergoing total parenteral nutrition. Gas troenterology. 95:394-401.

21. Hayashi, H., D. Nutting, F., K. Fujimoto, J. A. Cardelli, D. Black, and P. Tso. 1990. Transport of lipid and apolipoprotein A-I and A-IV in intestinal lymph of the rat. J. Lipid Res. 31:1613-1625.

22. Weinberg, R. B., C. Dantzker, and C. S. Patton. 1990. Sensitivity of serum apolipoprotein A-IV levels to changes in dietary fat content. Gastroenterology. 98:17-24.

23. Ordovas, J. M., D. K. Cassidy, F. Civeira, C. L. Bisgaier, and E. J. Schaefer. 1989. Familial apolipoprotein A-I, C-III and A-IV deficiency and premature atherosclerosis due to deletion of a gene complex on chromosome 11. J. Biol. Chem. 264:16339-16342.

24. Norum, R. A., J. B. Kakier, S. Goldstein, A. Angel, R. B. Goldberg, W. D. Block, D. K. Noffze, P. J. Dolphin, J. Edelglass, et al. 1982. Familial deficiency of apolipoprotein A-I and C-III and precocious coronary-artery disease. N. Engl. J. Med. 306:1513-1519.

25. Karathanasis, S. K., R. A. Norum, V. Zannis, and J. L. Breslow. 1983. An inherited polymorphism in the human apolipoprotein A-I gene locus related to the development of atherosclerosis. Nature (Lond.). 301:718-720.

26. Karathanasis, S. K., V. I. Zannis, and J. L. Breslow. 1983. A DNA insertion in the apolipoprotein A-I gene of patients with premature atherosclerosis. Nature (Lond.) 305:823-825.

27. Karathanasis, S. K., E. Ferris, and I. A. Haddad. 1987. DNA inversion within the apolipoprotein AI/CIII/AIV-encoding gene cluster of certain patients with premature atherosclerosis. Proc. Natl. Acad. Sci. USA. 84:7198-7202.

28. Fujimoto, K., J. A. Cardelli, and P. Tso. 1992. Increased apolipoprotein A-IV in rat mesenteric lymph after lipid meal acts as a physiological signal for satiation. Am. J. Physiol. 262:G1002-G1006.

29. Fujimoto, K., K. Fukagawa, T. Sakata, and P. Tso. 1993. Suppression of food intake by apolipoprotein A-IV is mediated through the central nervous system in rats. J. Clin. Invest. 91:1830-1833.

30. Steinmetz, A., and G. Utermann. 1985. Activation of lecithin:cholesterol acyltransferase by human apolipoprotein A-IV. J. Biol. Chem. 260:2258-2264.

31. DeLamatre, J. G., C. A. Hoffmeier, A. G. Lacko, and P. S. Roheim. 1983. Distribution of apolipoprotein A-IV between the lipoprotein and lipoprotein-free fractions of rat plasma: possible role of lecithin:cholesterol acyltransferase. $J$. Lipid Res. 24:1578-1585.

32. Stein, O., Y. Stein, M. Lefevre, and P. S. Roheim. 1986. The role of apolipoprotein A-IV in reverse cholesterol transport studied with cultured cells and liposomes derived from an ether analog of phosphatidylcholine. Biochim. Biophys. Acta. 878:7-13.

33. Dvorin, E., N. L. Gorder, D. M. Benson, and A. M. Gotto, Jr. 1986. Apolipoprotein A-IV. A determinant for binding and uptake of high density lipoproteins by rat hepatocytes. J. Biol. Chem. 261:15714-15718.

34. Bisgaier, C. L., M. V. Siebenkas, and K. J. Williams. 1989. Effects of apolipoproteins A-IV and A-I on the uptake of phospholipid liposomes by hepatocytes. J. Biol. Chem. 264:862-866.

35. Goldberg, I. J., C. A. Scheraldi, L. K. Yacoub, U. Saxena, and C. L. Bisgaier. 1990. Lipoprotein apoC-II activation of lipoprotein lipase. Modulation by apolipoprotein A-IV. J. Biol. Chem. 265:4266-4272.

36. Walsh, A., Y. Ito, and J. L. Breslow. 1989. High levels of human apolipoprotein A-I in transgenic mice result in increased plasma levels of small high density lipoprotein (HDL) particles comparable to Human HDL3. J. Biol. Chem. 264:6488-6494.

37. Saiki, R. K., D. H. Gelfand, S. Stoffel, S. J. Scharf, R. Higuchi, G. T. Horn, K. B. Mullis, and H. A. Erlich. 1988. Primer-directed enzymatic amplification of DNA with a thermostable DNA polymerase. Science (Wash. DC). 239:487-491.

38. Dammerman, M., L. A. Sandkuijl, J. L. Halaas, W. Chung, and J. L. Breslow. 1993. An apolipoprotein CIII haplotype protective against hypertriglyceridemia is specific by promoter and $3^{\prime}$ untranslated region polymorphisms. Proc. Natl. Acad. Sci. USA. 90:4562-4566.

39. Laurell, C. B., and E. J. McKay. 1981. Electroimmunoassay. Methods Enzymol. 73:339-369.

40. Seishima, M., C. L. Bisgaier, S. Davies, and R. M. Glickman. 1991. Regulation of hepatic apolipoprotein synthesis in the 17 alpha-ethinyl estradiol-treated rat. J. Lipid Res. 32:941-951.

41. Chomczynski, P., and N. Sacchi. 1987. Single-step method of RNA isolation by acid guanidinium thiocyanate-phenol-chloroform extraction. Anal. Bio chem. 162:156-159.

42. Williams, S. C., S. M. Bruckheimer, A. J. Lusis, R. C. LeBoeuf, and A. J. Kinniburgh. 1986. Mouse apolipoprotein A-IV gene: nucleotide sequence and induction by a high lipid diet. Mol. Cell Biol. 6:3807-3814.

43. Kates, M., B. Palameta, C. N. Joo, D. J. Kushner, and N. E. Gibbons. 1966. Aliphatic diether analogs of glyceride-derived lipids. IV. The occurrence of 
di- $O$-dihydrophytylglycerol ether containing lipids in extremely halophilic bacteria. Biochemistry. 5:4092-4099.

44. Weintraub, M. S., S. Eisenberg, and J. L. Breslow. 1987. Different patterns of postprandial lipoprotein metabolism in normal, type IIa, type III, and type IV hyperlipoproteinemic individuals. J. Clin. Invest. 79:1110-1119.

45. Aalto-Setälä, K., E. A. Fisher, X. Chen, T. Chajek-Shaul, T. Hayek, R Zechner, A. Walsh, R. Ramakrishnan, H. N. Ginsberg, and J. L. Breslow. 1992. Mechanisms of hypertriglyceridemia in human apolipoprotein (Apo) CIII transgenic mice. Diminished very low density lipoprotein fractional catabolic rate associated with increased apo CIII and reduced apo E on the particles. J. Clin. Invest. 90:1889-1900.

46. Folch, J., M. Lees, and G. H. Sloane Stanley. 1957. A simple method for the isolation and purification of total lipids from animal tissues. J. Biol. Chem. 226:497-509.

47. Zilversmit, D. B. 1972. A single blood sample dual isotope method for the measurement of cholesterol absorption in rats. Proc. Soc. Exp. Biol. Med. 140:862-865.

48. Kieft, K. A., T. M. A. Bocan, and B. R. Krause. 1991. Rapid on-line determination of cholesterol distribution among plasma lipoproteins after highperformance gel-filtration chromatography. J. Lipid Res. 32:859-866.

49. Laemmli, U. K. 1970. Cleavage of structural proteins during the assembly of the head of bacteriophage T-4. Nature (Lond.). 227:680-685.

50. Forte, T. M., and R. W. Nordhausen. 1986. Electron microscopy of negatively stained lipoproteins. Methods Enzymol. 128:442-457.

51. Ho, A., and A. Chin. 1988. Circadian feeding and drinking patterns of genetically obese mice fed solid chow diets. Physiol. Behav. 43:651-656.

52. Dole V. P., A. Ho, and T. Gentry. 1983. The improved technique for monitoring the drinking behavior of mice. Physiol. Behav. 30:971-974.

53. Blomhoff, R., M. H. Green, T. Berg, and K. R. Norum. 1990. Transport and storage of vitamin A. Science (Wash. DC). 250:399-404.

54. Kayden, H. J., and M. G. Traber. 1993. Absorption, lipoprotein transport and regulation of plasma concentration of vitamin $\mathrm{E}$ in humans. J. Lipid Res. 34:343-358

55. Agellon, L. B., A. Walsh, T. Hayek, P. Moulin, X. C. Jiang, S. A. Shelanski, J. L. Breslow, and A. R. Tall. 1991. Reduced high density lipoprotein cholesterol in human cholesteryl ester transfer protein transgenic mice. J. Biol. Chem. 260:10796-10801.

56. Plump, A. S., J. D. Smith, T. Hayek, K. Aalto-Setälä, A. Walsh, J. G. Verstuyft, E. M. Rubin, and J. L. Breslow. 1992. Severe hypercholesterolemia and atherosclerosis in apolipoprotein E-deficient mice created by homologous recombination in ES cells. Cell. 71:343-353.

57. Zhang, S. H., R. L. Reddick, J. A. Piedrahita, and N. Maeda. 1992 Spontaneous hypercholesteremia and arterial lesions in mice lacking apolipoprotein E. Science (Wash. DC). 258:468-471.

58. Shimano, H., N. Yamada, M. Katsuki, M. Shimada, T. Gotoda, K. Harada, T. Murase, C. Fukazawa, F. Takaku, and Y. Yazaki. 1992. Overexpression of apolipoprotein $E$ in transgenic mice: marked reduction in plasma lipoproteins except high density lipoprotein and resistance against diet-induced hypercholesterolemia. Proc. Natl. Acad. Sci. USA. 89:1750-1754.

59. Shimano, H., N. Yamada, M. Katsuki, K. Yamamoto, T. Gotoda, K. Harada, M. Shimada, and Y. Yazaki. 1992. Plasma lipoprotein metabolism in transgenic mice overexpressing apolipoprotein E: accelerated clearance of lipoproteins containing apolipoprotein B. J. Clin. Invest. 90:2084-2091

60. Marotti, K. R., C. K. Castle, R. W. Murray, E. F. Rehberg, H. G. Polites, and G. W. Melchior. 1992. The role of cholesteryl ester transfer protein in primate apolipoprotein A-I metabolism. Insights from studies with transgenic mice. Arterioscler. Thromb. 12:736-744.

61. Traber, M. G., G. W. Burton, K. U. Ingold, and H. J. Kayden. 1990. RRR- and SRR- $\alpha$-tocopherols are secreted without discrimination in human chylomicrons, but RRR- $\alpha$-tocopherol is preferentially secreted in very low density lipoproteins. J. Lipid Res. 31:675-685.

62. Traber, M. G., G. W. Burton, L. Hughes, K. U. Ingold, H. Hidaka, M. Malloy, L. Kane, J. Hyams, and H. J. Kayden. 1992. Discrimination between forms of vitamin $\mathrm{E}$ by humans with and without genetic abnormalities of lipoprotein metabolism. J. Lipid Res. 33:1171-1182.

63. Traber, M. G., R. J. Sokol, A. Kohlschütter, Y. Yokota, D. P. R. Muller R. Dufour, and H. J. Kayden. 1993. Impaired discrimination between stereoisomers of $\alpha$-tocopherol in patients with familial isolated vitamin E deficiency. $J$. Lipid Res. 32:201-210.

64. Traber, M. G., L. L. Rudel, G. W. Burton, L. Hughes, K. U. Ignold, and H. J. Kayden. 1990. Nascent VLDL from liver perfusions of cynomolgus monkeys are preferentially enriched in RRR-compared with SRR- $\alpha$-tocopherol: studies using deuterated tocopherols. J. Lipid Res. 31:687-694.

65. Ignold, K. U., G. W. Burton, D. O. Foster, L. Hughes, D. A. Lindsay, and A. Webb. 1987. Biokinetics of and discrimination between dietary RRR and SRR- $\alpha$-tocopherols in the male rat. Lipids. 22:163-172.

66. Sato, Y., K. Hagiwara, H. Arai, and K. Inoue. 1992. Purification and characterization of the $\alpha$-tocopherol transfer protein from rat liver. FEBS (Fed. Eur. Biochem. Soc.) Lett. 288:41-45.

67. Yoshida, H., M. Yusin, I. Ren, J. Kuhlenkamp, T. Hirano, A. Stolz, and N. Kaplowitz. 1992. Identification, purification and immunochemical characterization of a tocopherol-binding protein in rat liver cytosol. J. Lipid Res. 33:343350

68. Windler, E., Y.-S. Chao, and R. J. Havel. 1980. Regulation of the hepatic uptake of triglyceride-rich lipoproteins in the rat. Opposing effects of homologous apolipoprotein E and individual C apoproteins. J. Biol. Chem. 255:8303-8307.

69. Dvorin, E., W. W. Mantulin, M. F. Rohde, A. M. Gotto, Jr., H. J. Pownall, and B. C. Sherrill. 1985. Conformational properties of human and rat apolipoprotein A-IV. J. Lipid Res. 26:38-46.

70. Weinberg, R. B., and M. S. Spector. 1985. The self-association of human apolipoprotein A-IV. Evidence for an in vivo circulating dimeric form. J. Biol. Chem. 260:14279-14286. 